\title{
Propagules of arbuscular mycorrhizal fungi in a secondary dry forest of Oaxaca, Mexico
}

\author{
Patricia Guadarrama $^{1 *}$, Silvia Castillo-Argüero ${ }^{1}$, José A. Ramos-Zapata ${ }^{2}$, \\ Sara L. Camargo-Ricalde ${ }^{3}$ \& Javier Álvarez-Sánchez ${ }^{1}$ \\ 1 Depto. de Ecología y Recursos Naturales, Facultad de Ciencias, Universidad Nacional Autónoma de México (UNAM), \\ 04510 México D.F., México. Tel: (052) 55 56224835. Fax: (052) 55 56224828; *pgc@hp.fciencias.unam.mx \\ 2 Campus de Ciencias Biológicas y Agropecuarias, Universidad Autónoma de Yucatán. A.P. 4-116, Itzimná, C.P. 97000. \\ Mérida, Yucatán, México. \\ 3 Depto. Biología, Div. Ciencias Biológicas y de la Salud, Universidad Autónoma Metropolitana-Iztapalapa, Apdo. \\ Postal 55-535, 09340 México D.F., México.
}

Received 04-V-2006. Corrected 30-IV-2007. Accepted 14-V-2007.

\begin{abstract}
Plant cover loss due to changes in land use promotes a decrease in spore diversity of arbuscular mycorrhizal fungi (AMF), viable mycelium and, therefore, in AMF colonization, this has an influence in community diversity and, as a consequence, in its recovery. To evaluate different AMF propagules, nine plots in a tropical dry forest with secondary vegetation were selected: $0,1,7,10,14,18,22,25$, and 27 years after abandonment in Nizanda, Oaxaca, Mexico. The secondary vegetation with different stages of development is a consequence of slash and burn agriculture, and posterior abandonment. Soil samples (six per plot) were collected and percentage of AMF field colonization, extrarradical mycelium, viable spore density, infectivity and most probable number (MPN) of AMF propagules were quantified through a bioassay. Means for field colonization ranged between $40 \%$ and $70 \%$, mean of total mycelium length was $15.7 \pm 1.88 \mathrm{mg}^{-1}$ dry soil, with significant differences between plots; however, more than $40 \%$ of extracted mycelium was not viable, between 60 and 456 spores in $100 \mathrm{~g}$ of dry soil were recorded, but more than $64 \%$ showed some kind of damage. Infectivity values fluctuated between $20 \%$ and $50 \%$, while MPN showed a mean value of $85.42 \pm 44.17$ propagules (100 $\mathrm{g}$ dry soil). We conclude that secondary communities generated by elimination of vegetation with agricultural purposes in a dry forest in Nizanda do not show elimination of propagules, probably as a consequence of the low input agriculture practices in this area, which may encourage natural regeneration. Rev. Biol. Trop. 56 (1): 269-277. Epub 2008 March 31.
\end{abstract}

Key words: arbuscular mycorrhizal fungi (AMF), AMF field colonization, AMF spores density, most probable number (MPN), secondary vegetation, tropical dry forest.

In Mexico, the dry forest corresponds to $60 \%$ of tropical vegetation and shows a high degree of deterioration due to an expansion in agriculture and cattle raising (Trejo and Dirzo 2000). The change in land use generates a loss in plant diversity, as well as in soil microorganisms (Duponois et al. 2001).

Among soil microorganisms community, arbuscular mycorrhizal fungi (AMF) form mutualistic associations with most of the plant species (Newsham et al. 1995) and have a functional diversity which influences several aspects at community level, related to an increase in productivity and plant diversity (van der Heijden et al. 1998a, Munkvold et al. 2004).

Propagules of AMF (free spores and sporocarps in soil, extrarradical mycelium and colonized roots) establish a mycorrhizal association when they make contact with potential host species roots; propagules availability is influenced by environmental conditions (Guadarrama and Álvarez-Sánchez 1998), and its dynamics has been evaluated through estimation of abundance of spores in soil (Mangan et al. 2004), 
roots colonization (McGonigle and Miller 2000), extrarradical mycelium length (Jasper et al. 1989a) and, total viable propagules (An et al. 1998).

On the other hand, vegetation removal also influences AMF propagules activity and availability (Brundrett and Abbott 1994, Kabir et al. 1999, Boddington and Dodd $2000 \mathrm{a}, \mathrm{b}$ ) leading to a significant decrease in spores diversity, in the amount of viable mycelium and in colonization, as well as a loss in infectivity (Allen et al. 1998, Jasper et al. 1989b). Due to these changes the time required for the reestablishment of the original vegetation, as well as for diversity and productivity recovery will be longer (Cuenca et al. 1998, van der Heijden et al. 1998b).

In the Nizanda region, in the state of Oaxaca, Mexico, a heterogeneous landscape is observed and is characterized by secondary vegetation with different degrees of development as a consequence of slash and burn agricultural practices and posterior abandonment (Hernández X 1959). The land may be used for agriculture practice once or several times depending on particular characteristics of the site (v.g. slope and the location in relation to bodies of water), which might affect the AMF propagules, as well as the vegetation recovery, however, these dynamics has not yet been evaluated in Nizanda.

It is important to consider different types of AMF propagules to evaluate soil potential inoculum since focusing on only one type can give less reliable results; spores, for example, are produced in some species as result of environmental stress (McGee et al. 1997, Allen et al. 1998), as a consequence, high abundance of spores does not correlate to high root colonization or host benefit (Douds and Miller 1999); also, high root colonization does not imply a higher effectiveness (Clapperton and Reid 1992). To evaluate soil potential inoculum in secondary vegetation with different degrees of development in Nizanda, we have analyzed the AMF propagules (colonized roots, mycelium length, live spores, infectivity and infective propagules) and their densities in plots of different ages.

\section{MATERIALS AND METHODS}

Study site: Nizanda is located at $16^{\circ} 39^{\prime}$ $\mathrm{N}$ and $95^{\circ} 00^{\prime} \mathrm{W}$, in Oaxaca state, Mexico, and has an approximated area of $90 \mathrm{~km}^{2}$ (PérezGarcía and Meave 2006). Secondary vegetation in this region was originated from a tropical dry forest subjected to traditional agricultural practices of slash-burn with a posterior abandonment. The climate is $\mathrm{Aw}_{0}(\mathrm{w})$ igw" (García 1988 ) with $25{ }^{\circ} \mathrm{C}$ of mean temperature and 1 $000 \mathrm{~mm}$ of mean annual precipitation. Rains occur with a marked seasonality, therefore there are two seasons easily observed, the dry season, between November and April, and the rainy season, from May to October (SSP 1984a, b). Rocks from the Mesozoic are dominant, particularly metamorphic groups (schists), and limestone rocks from the inferior Cretaceous, the predominant soil types in the region are lithosols and, as secondary soils, haplic phaeozems and eutric regosols (SPP 1981). Mimosa acantholoba (Humb. \& Bonpl. ex Willd) Poir. (Leguminosae) is the dominant species in this secondary vegetation (Lebrija 2004).

Soil sampling: nine plots of $900 \mathrm{~m}^{2}$ each with secondary vegetation were established in a $2 \mathrm{~km}^{2}$ area of dry forest that has been used for agricultural practices with a subsequent abandonment. Each plot showed different ages since abandonment: one plot with zero years (sown and abandoned in the year of this study) and plots with 1, 7, 10, 14, 18, 22, 25, 27 years of abandonment. At the end of the rainy season (October 2004), six soil samples of $2 \mathrm{~kg}$ each were collected, from the first $15 \mathrm{~cm}$ of soil depth, cleaning the surface from litter, and then samples were dried at room temperature.

Field colonization: fine living roots (less than $2 \mathrm{~mm}$ in diameter) were separated from each soil sample, washed with tap water and stained according to Phillips and Hayman (1970) method. Permanent slides were elaborated and mycorrhizal colonization was quantified as stated by McGonigle et al. (1990) method. 
Extraradical mycelium: six 5 g subsamples from each soil sample were weighed, roots and rocks were removed and the AMF mycelium was separated according to Miller and Jastrow (1992) and Brundrett et al. (1994) techniques, mycelium was isolated from three sub-samples and stained with trypan blue, and the rest of them with tetrazolium in order to quantify total mycelium length and viable mycelium length respectively, using a modification of Tennats' method (Miller and Jastrow 1992, Brundrett et al. 1994).

Spore density: a $100 \mathrm{~g}$ soil sub-sample was taken from each collected soil sample to isolate spores by the wet-decanting (Gerderman and Nicolson 1963) and flotation in gradients of sucrose method (Daniels and Skipper 1982, modified by Brundett et al. 1996). Isolated spores were observed with a stereoscopic microscope, their viability was estimated, considering their turgidity, color and damage, counting was carried out taking into account alive, dead and total spores. We express density based on $100 \mathrm{~g}$ dry soil.

Infectivity and MPN: two greenhouse bioassays were carried out $\left(25{ }^{\circ} \mathrm{C}\right.$ and $80 \%$ moisture), the first one to estimate infectivity and the second one to evaluate the most probable number of infective propagules (MPN). For this, remnant soil from each plot was homogenized and a compound sample was obtained, and then passed through a $2 \mathrm{~mm}$ sieve.

To measure infectivity, $250 \mathrm{~g}$ of soil from each plot were used in $300 \mathrm{~g}$ capacity pot, with five replicates and Sorgum vulgarae L. seedlings as trap plants, which were previously germinated in a sterile substrate, according to Jasper et al. (1991). Each pot was watered daily and after six weeks, seedlings were harvested, roots were stained according to Phillips and Hayman (1970) method, and from each individual, permanent slides were elaborated for quantifying total colonization percentage (McGonigle et al. 1990).

To know the infective propagules number, the most probable number of infective propagules (MPN) bioassay was carried out (Porter 1979), using a four-fold soil dilution series, with five replicates and seven dilutions and an undiluted soil. S. vulgare was used as trap plant. Plants were watered everyday and after six weeks each plant was harvested. Roots were trypan blue stained according to Phillips and Hayman method (1970), and placed on permanent slides with PVLG (polivinilic alcohol-lactic acid-glycerine), to observe root colonization with help of a microscope.

Statistical analyses: data of field colonization, infectivity and live mycelium length were analyzed with one way ANOVA test. Abandonment time of plots was the factor, after testing for data normality, while spores viability was analyzed with a Kruskal-Wallis non parametric test (Zar 1999). The number of infective propagules (MPN) was analyzed with a likelihood test (Sprott 2000).

\section{RESULTS}

Percentages for AMF root field colonization were found to be between 40 and $69 \%$ in most plots, this value was smaller in the plot with 14 years of abandonment (29\%), nevertheless the ANOVA did not show significant differences ( $p>0.05)$ (Table 1).

Mean of total mycelium length was 15.7 $\pm 1.88 \mathrm{mg}^{-1}$ dry soil, nevertheless we found that only $40 \%$ of the mycelium was viable. With respect to the viable mycelium, length value was higher in the plot with one year of abandonment $\left(8.57 \pm 0.468 \mathrm{mg}^{-1}\right.$ dry soil) and the lowest value corresponded to the plot abandoned for 25 years $\left(2.96 \pm 9.661 \mathrm{mg}^{-1}\right.$ dry soil). The ANOVA test carried out showed significant differences only between these plots $(\mathrm{p}<0.05)$ (Fig. 1).

Between 60 and 456 spores were found in $100 \mathrm{~g}$ of dry soil, in 22 and 27 year old plots, but more than $64 \%$ showed some kind of damage, ANOVA test did not show significant differences $(p>0.05)$. For alive spores, plots with 18 and 22 years of abandonment 
TABLE 1

Mean values $( \pm S E)$ of field root colonization (\%), viable spores and infective propagules of soils from abandoned field in the tropical dry forest in Nizanda, Oaxaca

\begin{tabular}{|c|c|c|c|}
\hline $\begin{array}{c}\text { Time of abandonment } \\
\text { (years) }\end{array}$ & $\begin{array}{l}\text { Field root colonization } \\
\qquad(\%)\end{array}$ & $\begin{array}{l}\text { Viable spores } \\
\text { (100g dry soil) }\end{array}$ & $\begin{array}{l}\text { Infective propagules } \\
\text { (100g dry soil })\end{array}$ \\
\hline 0 & $44.7 \pm 4.3$ & $34.0 \pm 3.2$ & 37 bcd \\
\hline 1 & $47.0 \pm 8.1$ & $29.1 \pm 6.0$ & $14^{\mathrm{de}}$ \\
\hline 7 & $56.3 \pm 4.4$ & $18.1 \pm 2.8$ & $33^{\mathrm{cd}}$ \\
\hline 10 & $47.3 \pm 11.9$ & $35.5 \pm 3.8$ & $19^{\mathrm{d}}$ \\
\hline 14 & $29.3 \pm 5.3$ & $28.0 \pm 9.0$ & $35^{\mathrm{cd}}$ \\
\hline 18 & $51.6 \pm 4.09$ & $19.1 \pm 16.0$ & $421^{\mathrm{a}}$ \\
\hline 22 & $39.7 \pm 9.3$ & $34.0 \pm 10.1$ & $62 \mathrm{bc}$ \\
\hline 25 & $53.7 \pm 11.3$ & $25.1 \pm 8.5$ & $144^{\mathrm{ab}}$ \\
\hline 27 & $69.3 \pm 10.1$ & $23.4 \pm 3.6$ & $4^{e}$ \\
\hline
\end{tabular}

Values in same column followed with same letter are not significantly different.

showed between 16 and 18 spores (100 g dry soil), while the highest value of 110 spores corresponded to the 27 years old plot. KruskalWallis non parametric test showed significant differences for this variable $(\mathrm{H}=25.384, \mathrm{gl}=14$, $\mathrm{p}<0.05$ ) (Table 1).

On the other hand, estimated infectivity values in the bioassay were found to be close to $20 \%$ in the 25 and 27 years old plots, this value increased to $50 \%$ in the 18 years old plot. ANOVA test showed significant differences $(p<0.001), 18$ years old plot was different from the other ones except from the 1 year old abandonment plot, while this one was different to the 7 and the 25 years old plots (Fig. 2).

In relation to the number of viable propagules detected with the MPN method, a total mean of $85.42 \pm 44.17$ (100 g dry soil) was found, the lowest value was found in the plot with 27 years of abandonment (4) and the highest propagules number (421) was estimated in the plot abandoned for 18 years (Fig. 3).

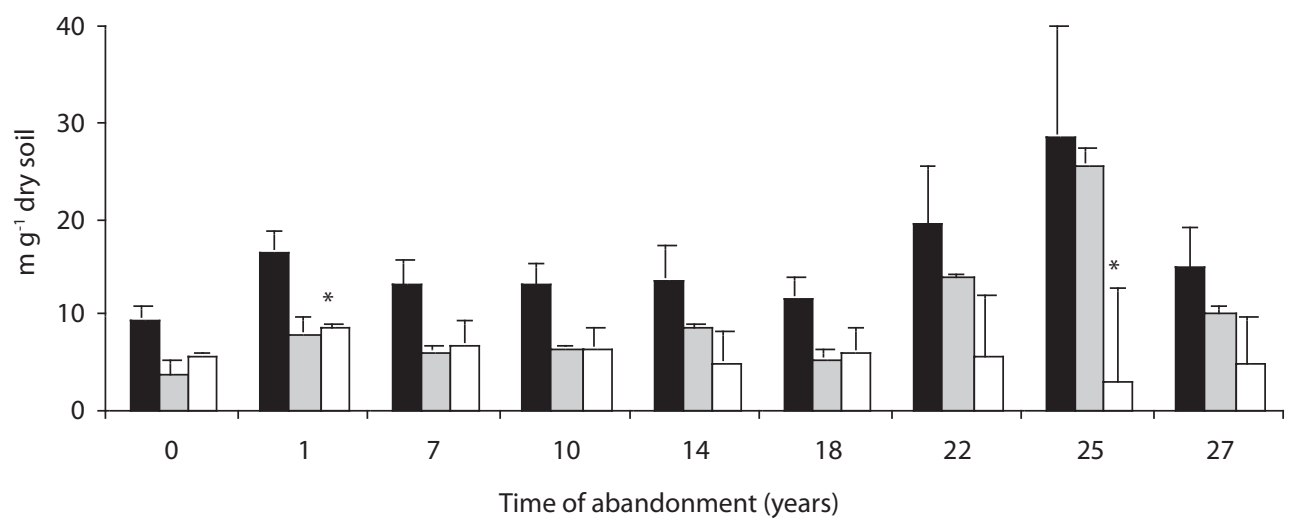

Fig. 1. Mean length of external mycorrhizal hyphae $(+\mathrm{SE})$ from soil samples from abandoned plots in the tropical dry forest in Nizanda, Oaxaca. Full bars $=$ total, gray bars $=$ dead, empty bars $=$ alive. Bars marked with $\left(^{*}\right)$ differ from each other at $\mathrm{p}<0.05(\mathrm{n}=21)$. 


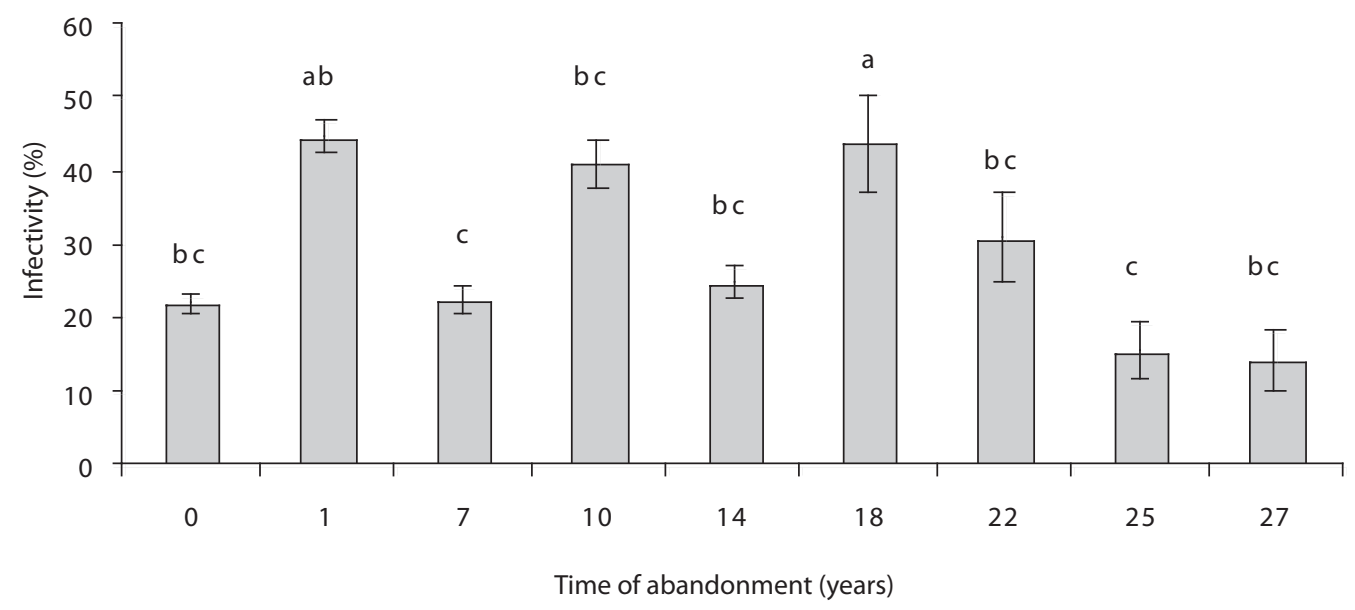

Fig. 2. Mean infectivity $( \pm$ SE) of soils from abandoned plots in the tropical dry forest in Nizanda, Oaxaca. Bars marked with same letters do not differ from each other at $\mathrm{p}<0.05(\mathrm{n}=21)$.

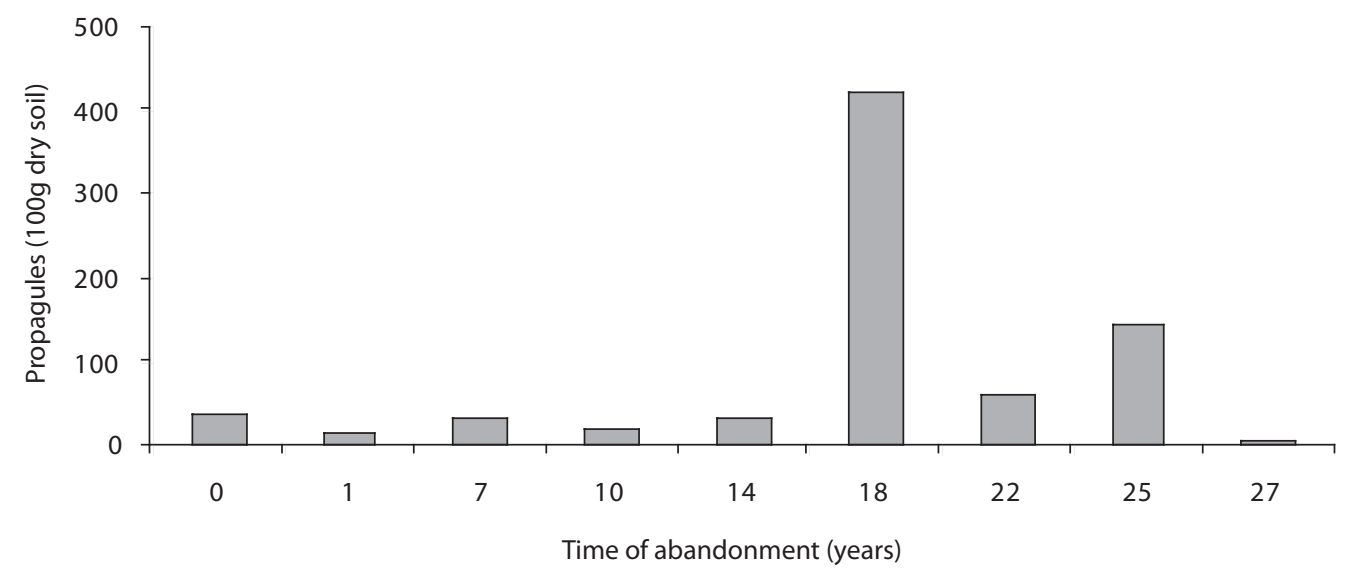

Fig. 3. Infective propagules in $100 \mathrm{~g}$ dry soil from abandoned plots in the tropical dry forest in Nizanda, Oaxaca.

Likelihood test showed five groups, where the 18 and the 27 years old plots differed most from the rest of the plots (Table 1).

\section{DISCUSSION}

The results showed the presence of AMF propagules in all plots, however there was not a clear relationship between the dynamics of AMF propagules and the time of abandonment of plots. Similar results have been previously reported in a tropical rain forest (Zangaro et al.
2000) and in a semi-evergreen tropical forest (Ramos-Zapata et al. 2006).

Presence of infective AMF propagules is important in the regeneration of vegetation since it offers benefits to the plants that support colonization, which depends on the inoculum type (spores, hyphae, colonized roots) and their density (McGee et al. 1997) that remains viable after disturbance. Boddington and Dodd (2000a) have pointed out that soil disturbance caused by agricultural activities has a direct effect on the availability of propagules, since richness and spore density are reduced, as well 
as the AMF extrarradical mycelium length. In contrast, in this study we found that the traditional agricultural practices in Nizanda do not reduce the AMF soil inoculum potential.

Spore density in this study is not related to the abandonment age of the sites which coincides with the study reported by Ingham and Wilson (1999) and contrasts with data obtained by Zangaro et al. (2000). They reported a value 50 times higher for the number of spores in soils from sites under recuperation when compared to forest soil; which depends on the plant species that established on abandoned sites in the former AMF community and on the edaphic conditions. It is important to mention that in our study only those spores that have the appearance to be viable are reported, since it is more important to consider only spores that may be able to promote mycorrhiza formation, which is not taken into account in other reports. Less than $50 \%$ of the quantified spores in our study were found to be viable in the abandoned plots.

In recently abandoned plots, with minor plant cover, AMF root field colonization was higher, which can be related to light intensity, as has been suggested by Gamage et al. (2004), who have studied the response of several species of Syzigium (Myrtaceae) to this variable and have found a high AMF root colonization when light amount was increased, suggesting that photosynthetic activity increases with a higher light intensity and, in consequence, the available carbohydrates for AMF development; in addition to the formation of lateral roots that increase the area for AMF entry points. However, we did not find significant differences between plots; similar results have been reported by Richter et al. (2002), who did not find differences in the AMF field root colonization percentages when compared with the results obtained between agricultural abandonment sites and grasslands.

Perturbation created by agricultural practices breaks the extrarradical mycelium in smaller units which may be rising up infection units, but as time goes by, a reduction of their infectivity occurs (Boddington and Douds 2000b), this effect can be caused by soil compaction (Drew et al. 2003). In this study, more than $40 \%$ of the extrarradical mycelium was found not to be viable, promoting a decrease in AMF infectivity. On the other hand, the infectivity bioassay indicated low percentages of AMF root colonization in soils from plots with longer times of abandonment, which is interpreted as a reduced number of infectivity propagules in those sites.

Extrarradical mycelium density determines the phosphorous uptake from soil, but efficiency depends on hyphae distribution and on the fungi species, in particular the highest efficiency of Acaulospora on Glomus and on Scutellospora has been proved (Jackobsen et al. 1992). Species identified in these plots (Guadarrama et al. 2007) indicated a higher dominance of Glomus species than of Acaulospora, although it is necessary to know the species composition in each plot to have a clear picture of AMF succession dynamics.

Inoculum potential decreases in the successional process, and propagule density in abandonment sites tends to increase to the point where it then decreases while plant recolonization process continues (Richter et al. 2002, Zangaro et al. 2000). In early stages of succession, Zangaro et al. (2000) found a higher number of spores and of inoculum potential in a tropical rain forest, due to the fact that pioneer species are dominant in these stages, and they are very efficient in AMF multiplication, which favors new seedling recruiting. On the contrary, plant species from later stages in succession are less dependent on AMF, they are weak multipliers and this is reflected in a low number of propagules in the forest soil. Ramos-Zapata et al. (2006) reported a higher number of propagules in a cornfield abandoned for 10 years originated from semi-evergreen tropical forest, when compared with natural surrounding vegetation, which could indicate that in latter successional stages the adequate host species are absent.

Results obtained in this study coincide with those reported by Zangaro et al. (2000) and Ramos-Zapata et al. (2006), since the number of propagules is low in recently abandoned 
plots, until reaching the highest values in the 18 years old plot, and afterwards it decreases, and in the plots with the longest period of abandonment, the smallest number of propagules was detected. Richter et al. (2002) mentioned that the soil inoculum potential does not depend only in the abandonment age, but also in the vegetation involved in the process of recolonization and on the persistent AMF species that are capable of reproducing themselves and colonizing new hosts through spores and hyphae fragments (Hart and Reader 2004). This is the reason why data analysis should involve the former AMF identity and their probable effect on seedling establishment and development.

In this study, different sources of propagules were measured in order to obtain a complete vision of their response to disturbance. Apparently the slash-burn agricultural practices applied in Nizanda do not cause a drastic disturbance on the AMF community. There probably is a rapid arrival of potential hosts during the first years of abandonment and, in consequence, the propagule density is high due to the incorporation of plants, as weed species, which stimulate the production of propagules (Jordan et al. 2000). We conclude that traditional slash-burn agricultural practices (low input agriculture) in Nizanda's tropical dry forest does not eliminate AMF propagules and in consequence does not affect their dynamics which may support the natural plant community regeneration.

\section{ACKNOWLEDGMENTS}

We thank Liliana Lara and Dora Trejo for helping in mycelium isolation techniques, Laura Hernández for assessing in spore viability and Eduardo Pérez-García, Yuriana Martínez, Diego Olivera, Oswaldo Núñez, Audra Paterson and Irene Sánchez-Gallén for technical assistance. This research was supported by DGAPA-IN221503.

\section{RESUMEN}

La vegetación secundaria con diferentes grados de desarrollo es consecuencia de prácticas agrícolas de rozatumba-quema y su posterior abandono. La remoción de la vegetación por cambios de uso de suelo promueve una disminución en la diversidad de esporas, micelio viable y por lo tanto de la colonización de los hongos micorrizógenos arbusculares (HMA), lo cual repercute en la diversidad de la comunidad y como consecuencia en su regeneración. Para evaluar los propágulos de HMA se seleccionaron nueve parcelas con vegetación secundaria con diferentes edades de abandono: 0, 1, 7, 10, 14, 18, 22, 25, 27 años, en la región de Nizanda, Oaxaca, México. Se recolectaron muestras de suelo (seis por parcela) y se cuantificó la colonización de campo, el micelio extrarradical, la densidad de esporas viables, así como la infectividad y el número más probable de propágulos infectivos (NMP). Los promedios de la colonización de campo fueron de 40 a $70 \%$, el promedio de la longitud de micelio total alcanzó $15.7 \pm 1.88 \mathrm{mg}^{-1}$ suelo seco con diferencias significativas entre parcelas, pero más del $40 \%$ del micelio extraído no fue viable. Se encontraron entre 60 y 456 esporas en $100 \mathrm{~g}$ de suelo pero más del $64 \%$ presentaron algún tipo de daño. Los valores de infectividad se encontraron entre $20 \%$ y $50 \%$, mientras que el NMP presentó un promedio de $85.42 \pm 44.17$ (100 g de suelo seco). Concluimos que las comunidades secundarias generadas por la eliminación de la vegetación con fines agrícolas en la selva baja caducifolia en Nizanda no presentan eliminación de propágulos, probablemente por el bajo impacto de la agricultura, lo cual indica que la regeneración natural es posible.

Palabras clave: hongos micorrizógenos arbusculares (HMA), colonización de campo, densidad de esporas, número más probable, vegetación secundaria, selva tropical caducifolia.

\section{REFERENCES}

Allen, E.B., E. Rincón, M.F. Allen, A. Pérez-Jiménez \& P. Huante. 1998. Disturbance and Seasonal dynamics of mycorrhizae in a tropical deciduous forest in Mexico. Biotropica 30: 261-274.

An, Z.Q., B.Z. Guo \& J.W. Hendrix. 1998. Viability of soilborne spores of Glomalean mycorrhizal fungi. Soil Biol. Biochem. 30: 1133-1136.

Boddington, C.L. \& J.C. Dodd. 2000a. The effect of agricultural practices on the development of indigenous 
arbuscular mycorrhizal fungi. I. Field studies in an Indonesian ultisol. Plant and Soil 218: 137-144.

Boddington, C.L. \& J.C. Dodd. 2000b. The effect of agricultural practices on the development of indigenous arbuscular mycorrhizal fungi. II. Studies in experimental microcosms. Plant Soil 218: 145-157.

Brundrett, M.C. \& L.K. Abbott. 1994. Mycorrhizal fungal Propagules in the Jarrah forest. I Seasonal study of inoculum levels. New Phytol. 127: 539-546.

Brundrett, M., L. Melville \& L. Peterson. 1994. Practical Methods in Mycorrhiza Research. Mycologue Publications, Ontario, Canada.

Brundrett, M., N. Bougher, B. Dell, T. Grove \& N. Malajczuk. 1996. Working with Mycorrhizas in Forestry and Agriculture. ACIAR Monograph, Camberra, Australia.

Clapperton, M.J. \& D.M. Reid. 1992. A relationship between plant growth and increasing VA mycorrhizal inoculum density. New Phytol. 120: 227-234.

Cuenca, G., Z. de Andrade \& G. Escalante. 1998. Arbuscular mycorrhizae in the rehabilitation of fragile degraded tropical land. Biol. Fert. Soil 26: 107-111.

Daniels, B.A. \& H.D. Skipper. 1982. Methods for the recovery and quantitative estimation of propagules from soil, p. 29-35. In N.C. Schenck (ed.). Methods and principles of mycorrhizal research. American Phytopathological Society, St. Paul, Minessotta, USA.

Douds, D.D. \& P.D. Jr. Miller. 1999. Biodiversity of arbuscular mycorrhizal fungi in agroecosystems. Agr. Ecosyst. Environ. 74: 77-93.

Drew, E.A., R.S. Murray, S.E. Smith \& I. Jakobsen. 2003. Beyond the rhizosphere: growth and function of arbuscular mycorrhizal external hyphae in sands of varying pore sizes. Plant and Soil 251: 105-114.

Duponnois, R., C. Plenchette, J. Thioulouse \& P. Cadet. 2001. The mycorrhizal soil infectivity and arbuscular mycorrhizal fungal spores communities in soils of different aged fallows in Senegal. Appl. Soil Ecol. 17: 239-251.

García, E. 1988. Modificaciones al sistema de clasificación climática de Köppen. Editado por la autora, México D.F., México.

Gamage, H.K., B.M.P. Singhakumara \& M.S. Ashton. 2004. Effects of Light and fertilization on arbuscular mycorrhizal colonization and growth in tropical rain-forest Syzygium tree seedlings. J. Trop. Ecol. 20: 525-534.

Gerdemann, J.W. \& T.H. Nicolson. 1963. Spores of mycorrhizal Endogone species extracted from soil by wet sieving and decanting. Trans. Brit. Myc. Soc. 46: 235-244.

Guadarrama, P. \& F.J. Álvarez-Sánchez. 1999. Abundance of arbuscular mycorrhizal fungi spores in different environments in a tropical rain forest, Veracruz, Mexico. Mycorrhiza 8: 267-270.

Guadarrama, P., S.L. Camargo-Ricalde, L. HernándezCuevas \& S. Castillo Argüero. 2007. Los hongos micorrizógenos arbusculares de la región de Nizanda, Oaxaca, México. Bol. Soc. Bot. México 81: 133-139.

Hart, M. \& R.J. Reader. 2004. Do arbuscular mycorrhizal fungi recover from soil disturbance differently? Trop. Ecol. 45: 97-111.

Hernández, X.E. 1959. La agricultura, p. 3-57. In Beltrán E. (ed.). Los recursos naturales del sureste y su aprovechamiento. IMRN, México D.F., México.

Ingham, E.R. \& M.V. Wilson. 1999. The mycorrhizal colonization of six wetland plant species at sites differing in land use history. Mycorrhiza 9: 233-235.

Jakobsen, I., L.K. Abbott \& A.D. Robson. 1992. External hyphae of vesicular-arbuscular mycorrhizal fungi associated with Trifolium subterraneum L. 1. Spread of hyphae and phosphorus inflow into roots. New Phytol. 120: 371-380.

Jasper, D.A., L.K. Abbott \& A.D. Robson. 1989a. Hyphae of a vesicular-arbuscular mycorrhizal fungus maintain infectivity in dry soil, except when the soil is disturbed. New Phytol. 112: 101-107.

Jasper, D.A., L.K. Abbott \& A.D. Robson. 1989b. Soil disturbance reduces the infectivity of external hyphae of vesicular-arbuscular mycorrhizal fungi. New Phytol. 112: 93-99.

Jasper, D.A., L.K. Abbott \& A.D. Robson. 1991. The effect of soil disturbance on vesicular-arbuscular mycorrhizal fungi in soils from different vegetation types. New Phytol. 118: 471-476.

Jordan, N.R., J. Zhang \& S. Huerd. 2000. Arbuscularmycorrhizal fungi: potencial roles in leed management. Weed Res. 40: 397-410.

Kabir, Z., I.P. O’Halloran \& C. Hamel. 1999. Combined effects of soil disturbance and fallowing on plant and fungal component of mycorrhizal corn (Zea mays L.). Soil Biol. Biochem. 31: 301-314. 
Lebrija, T.E.E. 2004. Secondary Sucesion in a Tropical Dry Forest of Southern Mexico. AV 2004-07, FEM 80328, Master Thesis, Wageningen, Netherlands.

Mangan, S.A., A.H. Eom, G.H. Adler, J.B. Yavitt \& E.A. Herre. 2004. Diversity of arbuscular mycorrhizal fungi across a fragmented forest in Panama: insular spore communities differ from mainland communities. Oecologia 141:687-700.

McGonigle, T.C. \& M.H. Miller. 2000. The inconsistent effect of soil disturbance on colonization of roots by arbuscular mycorrhizal fungi: a test of the inoculum density hypothesis. Appl. Soil Ecol. 14: 147-155.

McGonigle, T.P., M.H. Miller, D.G. Evans, G.L. Fairchild \& J.A. Swan. 1990. A new method which gives an objetive measure of colonization of roots by vesicular-arbuscular mycorrhizal. New Phytol. 115: 495-501.

McGee, P.A., G.S. Pattinson, R.A. Heath, C.A. Newman \& S.J. Allen. 1997. Survival of propagules of arbuscular mycorrhizal fungi in soils in Eastern Australia used to grow cotton. New Phytol. 135: 773-780.

Miller, R.M. \& J.D. Jastrow. 1992. Extraradical hyphal development of vesicular-arbuscular mycorrhizal fungi in a chronosequence of pairie restoration, $\mathrm{p}$. 171-176. In D.J. Read, D.H. Lewis, A.H. Fitter \& I.J. Alexander (eds.). Mycorrhizas in ecosystems. C.A.B. International, Wallingford, UK.

Munkvold, L., R. Kjøller, M. Vestberg, S. Rosendahl \& I. Jakobsen. 2004. High functional diversity within species of arbuscular mycorrhizal fungi. New Phytol. 164: $357-364$.

Newsham, K.K., A.H. Fitter \& A.R. Watkinson. 1995. Multi-functionality and biodiversity in arbuscular mycorrhizas. Trends Ecol. Evolut. 10: 407-411.

Pérez-García, E.A. \& J.A. Meave. 2006. Coexistence and divergence of tropical dry forests and savannas in southern Mexico. J. Biogeogr. 33: 438-447.

Phillips, J.M. \& D.S. Hayman. 1970. Improve procedures for cleaning roots and staining parasitic and vesicular-arbuscular mycorrhizal fungi for rapid assessment of infection. Trans. Brit. Myc. Soc. 55: 158-161.

Porter, W.M. 1979. The "Most Probable Number" Method for Enumerating Infective Propagules of Vesicular
Arbuscular Mycorrhizal Fungi in Soil. Aust. J. Soil Res. 17: 515-519.

Ramos-Zapata, J.A., R. Orellana \& E.B. Allen. 2006. Establisment of Desmoncus orthacanthos Martius (Aracaceae): effect of inoculation with arbuscular mycorrhizae. Rev. Biol. Trop.54: 65-72.

Richter, B.S., R.L. Tiller \& J.C. Stutz. 2002. Assessment of arbuscular mycorrhizal fungal propagules and colonization from abandoned agricultural fields and semiarid grasslands in riparian floodplains. Appl. Soil Ecol. 20: 227-238.

SPP (Secretaría de Programación y Presupuesto). 1981. Atlas Nacional del Medio Físico. México D.F., México.

SPP (Secretaría de Programación y Presupuesto). 1984a. Carta de Efectos Climáticos Regionales MayoOctubre. Juchitán E15-10 D15-1, Escala 1:250 000, México D.F., México.

SPP (Secretaría de Programación y Presupuesto). 1984b. Carta de Efectos Climáticos Regionales NoviembreAbril. Juchitán E15-10 D15-1, escala 1:250 000, México D.F., México.

Trejo, I. \& R. Dirzo. 2000. Deforestation of seasonally dry tropical forest: a national and local analysis in Mexico. Biol. Conserv. 94: 133-142.

van der Heijden, M.G.A., T. Boller, A. Wiemken \& I.R. Sanders. 1998a. Different arbuscular mycorrhizal fungal species are potential determinants of plant community structure. Ecology 79: 2082-2091.

van der Heijden, M.G.A., J.N. Klironomos, M. Ursic, P. Moutoglis, R. Streitwolf-Engel, T. Boller, A. Wiemken \& I.R. Sanders. 1998b. Mycorrhizal fungal diversity determines plant biodiversity, ecosystem variability and productivity. Nature 396: 69-72.

Sprott, D.A. 2000. Statistical inference in Science. SpringerVerlag, New York, USA.

Zar, J. 1999. Biostatistical Analysis. Prentice Hall, New Jersey, USA.

Zangaro, W., V.L.R. Bononi \& S.B. Truffen. 2000. Mycorrhizal dependency, inoculum potential and habitat preference of native woody species in South Brazil. J. Trop. Ecol. 16: 603-622. 
